\title{
IMPLEMENTATION COST CALCULATION USING ABC METHOD Sebastian UNGUREANU
}

\author{
"Al. I. Cuza" Universitv, Iasi, Romania \\ sebastian_ungureanu2000@yahoo.com
}

\begin{abstract}
The cost information system plays an important role in every organization in the decision making process. An important task of management is to ensure control of the operations, processes, sectors of activity and not finally, on costs. Although the objectives of an organization contributes with more control systems (production control, quality control etc.), the cost information system is important because it monitors the results of others. The detailed analysis of costs, production cost calculation, quantification of losses, the work efficiency estimation provide a solid basis for financial control. Knowledge of cost is a decisive factor in taking decisions and planning future activities. Managers are concerned about the costs that will appear in the future, their level underpinning the supply and production decisions and pricing policies. An important factor is the cost efficiency of the information system so that the information provided by it is useful for decision support and planning the activities.
\end{abstract}

\section{Keywords: the informational system of cost, production cost, allocation, financial control}

\section{Introduction}

Activity Based Costing (ABC) is a cost allocation method based on identifying key operational activities, the classification of expenses by activity and reduction or total elimination of those activities that do not generate value. According to $\mathrm{ABC}$, the costs are allocated to the activity that generated them [1]. Initially, the method of Activity Based Costing (ABC) appeared in the USA in the late $80 \mathrm{~s}$ as a result of work submitted by the group "International Consortium for Advanced Machining" (CAMI).

The appearance and the need for $\mathrm{ABC}$ is explained by:

- intensifying both in absolute terms and relative to indirect costs in most sectors of the economy;

- the changes in the nature of indirect costs. Because of the increasing complexity and diversity of products produced, the share of indirect costs increased to an extent greater than the weight variable costs, which are in direct correlation with the volume of production achieved [2];

- the manner in which direct labor is performed. During the time, the extent of direct labor cost reflected in the total cost was becoming smaller, which contributed to the reduction of labor unit using indirect cost allocation.

\section{Costing method based on activities}

The basic idea, which stems from the principles of the $\mathrm{ABC}$ method is that traditional accounting information is useful to managers, who are interested in assessing the effectiveness of resource allocation decisions in their companies. This information exchange is involved in traditional meeting external auditors or others who are interested in financial accounting records. 
The organization of management accounting and cost calculation using the activity-based costing is based on the following premises: a. widespread use of the method of costing the activities;

The choice of method ABC was made taking into consideration the organizational factors of management accounting and cost calculation, such as company size, use of technology, the number of products, meaning indirect costs and competition.

$b$. setting the interval for the conduct of operations, economic-financial and determination of costs;

In order to not distort costs in the year kept reporting period Predefined and postcalculation were chosen. Thus, according to company specifics, selected reporting period is related to month or quarter, but with some exceptions, and annually.

c. finding the staff responsible for the collection, compilation, processing, analysis and reporting of information generated by the management accounting and costing;

In the case of the ABC method, each functional department has a representative in charge of developing the Predefined work and post-calculation, cost calculation being performed at the level of functional service, and thus responsibility and accountability rest on its preparation. All budgets are then collected by the accounting structure of the company and are subject to approval by management.

d. the timing of specific works in management accounting and cost calculation;

This is closely related to the previous one, and finding the way of the fulfillment of the tasks undertaken by departments is performed using graphics or tabular statements and may take various forms, depending on the requirements of the company management.

e. setting the manner of processing information generated by the management accounting;

Since the method $\mathrm{ABC}$ requires a huge volume of data entry and processing, it is necessary processing them using advanced software.

$f$. processes and activities and their role in management accounting and costing.

The processes represent a group of two or more activities involved in a common goal, being joined together by the same types of streams (the material and/or information), as in the case of the family of processes [3]. The process provides an internal or external product or service. All activities within the framework of a process bind the formation logically taking into account the "output" acquisition process that proceeds to sorting activities from those in the past to the future. The operation is based on the analysis of actions in achieving their tasks (e.g. visiting showrooms, establishing contracts etc.). The operation requires mandatory participation in an activity [4]. In carrying out the technological process of implementation it is envisaged that each operation to be executed in the limited time. Given the conduct of specific activities reported to the period, we can identify the following activities:

- activities related to the production planning, product design and development;

- support activities of production and economic environment as a whole;

- current organizational activities conducted in order to ensure the smooth running of the company.

The quantitative measurement of the output obtained is performed using calculation units, which takes two forms: natural and conventional. The calculation of physical units includes: technical measurement units such as meter, square meter, panel, piece, pair etc. The category of conventional calculation units contains the units of time (number of hours produced, number of hours for testing, for processing, for executing maintenanc) and referential form (batch number launched, monthly contact number, number summary sheets, number of exinvestment contact number, number collaboration etc.). According to the $\mathrm{ABC}$ method, the data processed in order to be 
registered in management accounting is done as follows [5]:

- identifying processes within the company: supply, quality assurance program, production program, commercialization process, shipping process;

- identifying the main activities in the process.

In order to implement the method of cost, the activities necessary to determine the main stages in the development of the production process are as follows:

- identification and analysis of the cost of activities on which allocation of indirect is done. They lay the foundation of a model on activities of the company or a department is implemented this method. Thus, we proceed to describe the company and the interdependencies between them; through this "mapping activities" the managerial resources and effort are directed to the real problems of the company [6].

- costs collection, which must establish the causal link between the consumption of resources and the activities so that the generated unnecessary costs that do not provide valuable and relevant cost accounting are removed.

- identifying the factors that determine the cost of an activity called cost drivers and the calculation of unit costs for these inductors.

The volume of cost drivers can be established on the basis of the technical information on the manufacturing process of the products produced by a company [7]. The unit cost of an inductor cost is determined by the ratio between the total cost of the activity and the total cost of the total output inductor made.

- cost sharing activities worth bearing.

The ABC method is based on the principle that activities generate costs, and carriers of value are those who "create" demand for those activities. The costs of each activity are attributed to each of the component processes of production.

\section{Possibilities of implementing the $\mathrm{ABC}$ method}

In the Division of aeronautical products, the production plan for November 2013 contained under contract repair and maintenance activities with a large airline, according to table. 1 .

Table no. 1: Extract from the production plan of the Aviation Products Division, November 2013

\begin{tabular}{|c|c|c|c|c|c|c|}
\hline No & The product & Quantity & $\begin{array}{c}\text { Selling } \\
\text { price }\end{array}$ & $\begin{array}{l}\text { Total } \\
\text { value }\end{array}$ & $\begin{array}{l}\text { The direct } \\
\text { costs } \\
\text { allocated }\end{array}$ & $\begin{array}{c}\text { The indirect } \\
\text { costs } \\
\text { allocated }\end{array}$ \\
\hline 1 & $\begin{array}{l}\text { Sunroof niche outside profiled } \\
\text { leg }\end{array}$ & 50 & 4,200 & 210,000 & \multirow{12}{*}{$1,728,000.00$} & \multirow{12}{*}{$1,108,646.00$} \\
\hline 2 & Jamba outer main & 50 & 2,800 & 140,000 & & \\
\hline 3 & Rotary joints & 200 & 1,700 & 340,000 & & \\
\hline 4 & Landing gear outer wheel & 40 & 8,000 & 320,000 & & \\
\hline 5 & Outer wheel assembly & 40 & 5,000 & 200,000 & & \\
\hline 6 & Outer wheel brake assembly & 40 & 6,000 & 240,000 & & \\
\hline 7 & Previous wheel landing gear & 30 & 7,500 & 225,000 & & \\
\hline 8 & Previous wheel assembly & 30 & 4,000 & 120,000 & & \\
\hline 9 & Previous wheel brake assembly & 30 & 5,200 & 156,000 & & \\
\hline 10 & The main landing gear wheel & 60 & 8,500 & 510,000 & & \\
\hline 11 & Main wheel assembly & 60 & 8,100 & 486,000 & & \\
\hline 12 & Main wheel brake assembly & 60 & 7,500 & 450,000 & & \\
\hline
\end{tabular}

Source: own calculations performed, the data are taken from www. Aerostar.ro 
Direct and indirect costs in Table. 1 were included in the expenditure budget of the Aeronautical Products Division, 2013. Implementing this method of cost calculation aerospace products in SC Aerostar S.A. Bacău involves the following steps:

1. identifying poles and cost analysis activities undertaken by the company in order to provide the basis for allocation of costs. To apply this method of costing it is necessary to know in detail the company's activities and relationships. Thus, the Division of aeronautical product and the desired implementation of this method of cost calculation identified the following poles of cost:

- research;

- supply;

- production;

- actions carried out in production (financial accounting, sales, marketing, human resources, staff training).

The activities of these poles corresponding to the cost and resource allocation for each activity are presented in Table 2 . The company resources and managerial effort through the "mapping of activities" [8] are directed to the basic functions of the company and not to organizational structure elements. Determining the cost of resources must be done before the start of the reporting period to which they relate, so the spending budget system is relevant to the $\mathrm{ABC}$ calculation method.

Table no. 2: Elements of the calculation

\begin{tabular}{|c|c|c|c|c|c|}
\hline No. & $\begin{array}{l}\text { Pole cost } \\
\text { (relationship with } \\
\text { regrouping centers) }\end{array}$ & $\begin{array}{l}\text { Indirect } \\
\text { costs }\end{array}$ & Activities & $\begin{array}{l}\text { The cost } \\
\text { of } \\
\text { activity }\end{array}$ & Cost drivers \\
\hline 1 & Research & 10,234 & Research & 10,234 & $\begin{array}{l}\text { Number of hours } \\
\text { research }\end{array}$ \\
\hline \multirow{3}{*}{2} & \multirow{3}{*}{ Supply } & \multirow{3}{*}{452,345} & Study suppliers & 23,856 & Number of suppliers \\
\hline & & & Orders raw materials & 402,857 & Number of Orders \\
\hline & & & Stocks & 25,632 & $\begin{array}{l}\text { Reference number of } \\
\text { raw materials }\end{array}$ \\
\hline \multirow[t]{2}{*}{3} & \multirow[t]{2}{*}{ Output } & \multirow[t]{2}{*}{543,683} & $\begin{array}{l}\text { Preparation and launch into } \\
\text { production }\end{array}$ & 40,731 & Number of lots \\
\hline & & & Manufacture & 502,952 & Direct labor hours \\
\hline \multirow[b]{2}{*}{4} & \multirow{2}{*}{$\begin{array}{l}\text { Outside production } \\
\text { (Sales, Marketing, } \\
\text { Financial Accounting, } \\
\text { Human Resources, } \\
\text { Training staff) }\end{array}$} & \multirow[b]{2}{*}{102,384} & Marketing of products & 53,801 & Number of Products \\
\hline & & & Administration and finance & 48,583 & Cost added \\
\hline & Total & $1,108,646$ & & $1,108,646$ & \\
\hline
\end{tabular}

Source: own calculations performed, the data are taken from www. Aerostar.ro

2. identification of cost drivers, their share in the total cost drivers in the sector of activity, and the unit cost.

Thus, in the 'cost drivers "in the Product Division Aviation the identified activities in the industry were grouped in the following cost drivers:

- number of hours for research;

- number of suppliers;

- number of orders;

- reference number of raw materials;
- number of lots;

- direct hours of labor;

- number of products;

- $\quad$ added cost.

Based on the technical information on manufacturing the conditions of the products produced by the company realized the volume of each inductor sizing cost. Volume following cost drivers: number of hours for research, number of suppliers, raw material reference number, batch number and number 
of products include common inducers number of 12 products. Inductor "direct hours of labor" was calculated by multiplying the quantity of products manufactured with the number of direct... of labor hours for each product and the inductor "added cost" is calculated as the difference between the total cost of all activities and the cost of specific administrative and financial structure activities.

In table 3 the cost of each inductor was calculated, being determined as the ratio between the cost of each activity and the volume related to cost drivers.

\section{3. product cost allocation activities}

The allocation of costs to production work is done by the following calculation:

- the volume allocated inductor product collects the difference between the total cost drivers and cost drivers total amount allocated to all these products multiplied by the ratio in which the accused shared the cost drivers;

- the result is multiplied by the average cost of the related cost drivers. (Product Cost allocation activities)

Table no. 3: Calculation of costs drivers

\begin{tabular}{|c|c|c|c|c|c|}
\hline No. & Activities & $\begin{array}{l}\text { The cost of } \\
\text { activity }\end{array}$ & Cost drivers & $\begin{array}{l}\text { Volume } \\
\text { inductor cost } \\
\quad \text { (total) }\end{array}$ & $\begin{array}{l}\text { The cost } \\
\text { inductor }\end{array}$ \\
\hline 0 & 1 & 2 & 3 & 4 & 5 \\
\hline 1 & Research & 10,234 & $\begin{array}{l}\text { No. research } \\
\text { hours }\end{array}$ & 480 & 21.32 \\
\hline 2 & Study suppliers & 23,856 & $\begin{array}{l}\text { Number of } \\
\text { suppliers }\end{array}$ & 130 & 183.51 \\
\hline 3 & Orders raw materials & 402,857 & $\begin{array}{l}\text { Number of } \\
\text { Orders }\end{array}$ & 213 & $1,891.35$ \\
\hline 4 & Stocks & 25,632 & $\begin{array}{l}\text { Reference } \\
\text { number of raw } \\
\text { materials }\end{array}$ & 350 & 73.23 \\
\hline 5 & $\begin{array}{l}\text { Preparation and launch into } \\
\text { production }\end{array}$ & 40,731 & Number of lots & 40 & $1,018.28$ \\
\hline 6 & Manufacture & 502,952 & Direct labor hours & 4,280 & 117.51 \\
\hline 7 & Marketing of products & 53,801 & $\begin{array}{l}\text { Number of } \\
\text { Products }\end{array}$ & 18,000 & 2.99 \\
\hline 8 & Administration and finance & 48,583 & Cost added & $1,060,063$ & 0.05 \\
\hline 9 & Total & $1,108,646$ & & $\mathrm{x}$ & $\mathrm{x}$ \\
\hline
\end{tabular}

Source: own calculations performed, the data are taken from www. Aerostar.ro

4. determination of product costs and unit and global profit

At this stage the following indicators are established: indirect cost unit, unit cost of production, unit profit and total profit. The calculation of these indicators is presented in Table no. 4.

\section{Conclusions}

The analysis and interpretation of results leads to the following conclusions:

○ the company achieved a gross profit of 560,354 lei which represents a rate of about $65 \%$ of the goods sold;

- manufacture of "main profiled leg outside" a loss for the company, but since the product "outer profiled leg hatch" produces a significant profit, the company does compromise the security reasons, because it is necessary for the two parts to be replaced together;

○ manufacture of "rotary joints" also produces a loss, but this loss is subsidized by other parts sold, the rotary joints being used to mount the landing gear and wheels;

- referral to these products that generate loss is only possible through this method of allocating indirect costs on 
activities and cost drivers, as they can easily highlight the activities that produce added value; in our case it was very difficult company recorded profit by the costing another method to identify loss in case of those products.

Table no. 4: Determination of product costs and profits and global unit

\begin{tabular}{|c|c|c|c|c|c|c|c|c|c|c|c|c|c|}
\hline & \multirow[b]{2}{*}{ Explanations } & \multicolumn{12}{|c|}{ Indirect expenses allocated } \\
\hline & & $\begin{array}{l}\text { Sunroof } \\
\text { niche } \\
\text { outside } \\
\text { profiled } \\
\text { leg } \\
\end{array}$ & $\begin{array}{r}\text { Jamba } \\
\text { outer } \\
\text { main }\end{array}$ & $\begin{array}{l}\text { Rotary } \\
\text { joints }\end{array}$ & $\begin{array}{c}\text { Landing } \\
\text { gear } \\
\text { outer } \\
\text { wheel }\end{array}$ & $\begin{array}{c}\text { Outer } \\
\text { wheel } \\
\text { assembly }\end{array}$ & $\begin{array}{l}\text { Outer } \\
\text { wheel } \\
\text { brake } \\
\text { assembly }\end{array}$ & $\begin{array}{l}\text { Previous } \\
\text { wheel } \\
\text { landing } \\
\text { gear }\end{array}$ & $\begin{array}{l}\text { Previous } \\
\text { wheel } \\
\text { assembly }\end{array}$ & $\begin{array}{c}\text { Previous } \\
\text { wheel } \\
\text { brake } \\
\text { assembly }\end{array}$ & $\begin{array}{c}\text { The } \\
\text { main } \\
\text { landing } \\
\text { gear } \\
\text { wheel }\end{array}$ & $\begin{array}{c}\text { Main } \\
\text { wheel } \\
\text { assembly }\end{array}$ & $\begin{array}{c}\text { Main } \\
\text { wheel } \\
\text { brake } \\
\text { assembly }\end{array}$ \\
\hline 0 & 1 & 2 & 3 & 4 & 5 & 6 & 7 & 8 & 9 & 10 & 11 & 12 & 13 \\
\hline 1 & $\begin{array}{l}\text { Quantities } \\
\text { sold }\end{array}$ & 50 & 50 & 200 & 40 & 40 & 40 & 30 & 30 & 30 & 60 & 60 & 60 \\
\hline 2 & $\begin{array}{c}\text { Indirect } \\
\text { expenses } \\
\text { allocated }\end{array}$ & 69,595 & 59,893 & 120,737 & 100,440 & 72,533 & 86,372 & 71,249 & 40,422 & 47,848 & 160,587 & 154,245 & 124,724 \\
\hline 3 & $\begin{array}{c}\text { Indirect Cost } \\
\text { Unit }\end{array}$ & 1,392 & 1,198 & 604 & 2,511 & 1,813 & 2,159 & 2,375 & 1,347 & 1,595 & 2,676 & 2,571 & 2,079 \\
\hline 4 & $\begin{array}{l}\text { Direct cost } \\
\text { unit }\end{array}$ & 2,000 & 1,800 & 1,500 & 3,500 & 2,600 & 2,800 & 3,400 & 2,100 & 2,300 & 4,100 & 3,600 & 3,100 \\
\hline 5 & $\begin{array}{c}\text { Unit } \\
\text { production } \\
\text { cost (euro / } \\
\text { pcs.) } \\
\end{array}$ & 3,392 & 2,998 & 2,104 & 6,011 & 4,413 & 4,959 & 5,775 & 3,447 & 3,895 & 6,776 & 6,171 & 5,179 \\
\hline 6 & $\begin{array}{l}\text { Sale price } \\
\text { (Euro / pcs.) }\end{array}$ & 4,200 & 2,800 & 1,700 & 8,000 & 5,000 & 6,000 & 7,500 & 4,000 & 5,200 & 8,500 & 8,100 & 7,500 \\
\hline 7 & $\begin{array}{l}\text { Unit profit } \\
\text { (lei / pcs.) }\end{array}$ & 808 & -198 & -404 & 1,989 & 587 & 1,041 & 1,725 & 553 & 1,305 & 1,724 & 1,929 & 2,321 \\
\hline 8 & Total profit & 40,405 & $-9,893$ & $-80,737$ & 79,560 & 23,467 & 41,628 & 51,751 & 16,578 & 39,152 & 103,413 & 115,755 & 139,276 \\
\hline
\end{tabular}

Source: own calculations performed, the data are taken from www. Aerostar.ro

\section{References}

[1] Smith, J.A., Management Accounting. $4^{\text {th }}$ Edition, New York, Elsevier Publishing, 2007, pp. 425-427.

[2] Jones, M., Accounting, Second Edition. Cardiff, John Wiley \& Sons, 2006, pp. 407-410.

[3] Budugan, D., Contabilitate şi control de gestiune, Iaşi, Editura Sedcom Libris, 2002, p. 53.

[4] Swain, M.R., Albrecht, W.S., Stice, J.D., Stice, E.K., Management Accounting, Thomson Learning South Western, 2008, pp. 456 - 458.

[5] Seal, W., Garrison, R.H., Noreen, E.W., Management Accounting. $3^{\text {rd }}$ Edition, New York, The Mc Graw - Hill Companies, 2012, pp. 275-280.

[6] Williams, J. R., Haka, S. F., Bettuer, M. S., Financiar \& Managerial Accounting, The Basis for Business Decisions, Editura Mc Graw - Hill, 2013, pp. 750 - 759.

[7] Briciu, S., Căpuşneanu, S., Rof, L., M., Topor, D., Contabilitatea şi controlul de gestiune, instrumente pentru evaluarea performanţei entităţii, Alba Iulia, Editura Aeternitas, 2010, p. 339.

[8] Budugan, D., Georgescu, I., Berheci, I., Beţianu, L., Contabilitate de gestiune. Bucureşti: Editura CECCAR, 2007, p. 463. 